\title{
QSAR STUDY BY 1,2,4-TRIAZOLES USING SEVERAL PHYSICOCHEMICAL DESCRIPTORS
}

\author{
Vesna Dimova ${ }^{1}$, Nada Perišić-Janjić ${ }^{2}$ \\ ${ }^{1}$ Faculty of Technology and Metallurgy, SS. Cyril and Methodius University, \\ P.O. Box 580, MK-1001 Skopje, Republic of Macedonia \\ ${ }^{2}$ Institute of Chemistry, Faculty of Sciences, \\ Trg Dositeja Obradovića 3, 21000 Novi Sad, Serbia \\ vdimova@tmf.ukim.edu.mk
}

\begin{abstract}
A QSAR study on the inhibition of Bacillus subtilis and Salmonella enteritidis by 1,2,4-triazoles using several physicochemical descriptors was performed. The 1,2,4-triazoles consist of 18 derivatives with $\mathrm{N}^{1}$-aryl- or $\mathrm{N}^{1}$ heteroaryl substituted rings and having aminomethyl or aminoethyl unit. The 6 best models were selected for the discussion. Initial regression analysis indicated that $\eta$ plays a dominating role in modelling the activity in all proposed models. The correlation coefficients were $0.80-0.99$ in all cases, and the standard deviation was below 0.42 . Good cross-validation $Q^{2}$ values were obtained $\left(Q^{2}>0.72\right)$. The ratio of PRESS/SSY ranges between $0.002-0.169$, indicating that all proposed models are reliable QSAR models. A statistically significant result for the bacterial inhibitory activity of the chosen triazole derivatives against $S$. enteritidis, using the eight descriptors, was not obtained.
\end{abstract}

Key words: QSAR; 1,2,4-triazole; surface tension; index of refraction; $Q^{2}$ values

\section{QSAR-СТУДИЈА НА 1,2,4-ТРИАЗОЛИ СО ПРИМЕНА НА НЕКОИ ФИЗИЧКО-ХЕМИСКИ ДЕСКРИПТОРИ}

\begin{abstract}
Cо користење на физичко-хемиски дескриптори е изработена QSAR-студија за инхибиционото дејство на 1,2,4-триазоли во однос на Bacillus subtilis и Salmonella enteritidis. Серијата на 1,2,4-триазоли се состои од 18 деривати кои содржат супституирани јадра на $\mathrm{N}^{1}$-арил- и $\mathrm{N}^{1}$-хетероарил, како и групи на аминометил и аминоетил. Најдобрите 6 модели се анализирани и од анализата може да се заклучи дека параметарот $\eta$ има доминантно влијание при моделирањето на активноста во сите предложени модели. Кај сите модели корелационите коефициенти се задоволителни $(R=0,80-0,99)$ и стандардните девијации се под 0,2. Добиени се и добри вредности за коефициентот $Q^{2}\left(Q^{2}>0,72\right)$. Вредностите на PRESS/SSY се движат во границите од $0,002-0,169$, што укажува на фактот дека сите предложени модели се веродостојни. Не се добиени задоволителни резултати за бактериската активност на избраните триазолни соединенија во однос на Salmonella enteritidis.
\end{abstract}

Клучни зборови: QSAR; 1,2,4-триазол; површински напон; индекс на рефракција; вредности $Q^{2}$

\section{INTRODUCTION}

The investigation of the quantitative structure activity/property relationships $(Q S A R / Q S P R)$ of substances is an important aspect of modern chemistry, biochemistry, medicinal chemistry, and drug discovery [1-6]. The information obtained is composed of mathematical equations relating the chemical structure of the compounds to a wide variety of their physical, chemical, biological and technological properties. Once a correlation between structure and activity/property is found, any number of compounds, including those not synthesized yet, can readily be screened in silico for selection of structures with desired properties. Hence, it is possible to select the most promising compounds for synthesis and testing in the laboratory. 
The recent findings that the 1,2,4-triazole nucleus is associated with diverse biological activities such as analgetic, antiasthmatic, diuretic, antihypertensive, antibacterial, antifungal and antinflammatory properties [7-14], prompted us to synthesize some new 1,2,4-triazole derivatives and to investigate their antibacterial and antifungal activities. The Mannich reaction (aminomethylation) of some heterocycles (benzotriazoles, benzimidazoles), formaldehyde and aliphatic and aromatic amines is well established [15]. N-hydroxyethyl derivatives of heterocycles, under the influence of amines, can also yield the corresponding Mannich bases $[15,16]$. It is also known that some aminomethyl heterocycles possess biological and corrosion-inhibition activities, and can be used as additives in greasy oils as well as photopolymerizing paints for improving adhesion [17-22].

Spurred by the need of new antimicrobial agents and the fact that many new effective antimicrobial drugs possess heterocyclic rings in their structure, we synthesized and investigated several new 1,2,4-triazole derivatives during the last few years [23-26]. A group of $18 \mathrm{~N}^{1}$-aryl/heteroarylaminomethyl/ethyl-1,2,4-triazoles was synthesized (Figure 1; Table 1) by condensation of a hydroxymethyl derivative of 1,2,4-triazole and the appropriate aromatic/heteroaromatic amines, and by reaction of 1,2,4-triazole, acetaldehyde and few aromatic/heteroaromatic amines. All synthesized compounds were screened for their antibacterial and antifungal activities against Bacillus subtilis and Salmonella enteritidis [23].

\section{EXPERIMENTAL}

\section{Materials}

All $\mathrm{N}^{1}$-aryl/heteroarylaminomethyl/ethyl-1,2,4triazole derivatives (1-18), (Fig. 1, Table 1) used in this study were already synthesized, as reported elsewhere [23].

$1 H-1,2,4$-triazole in reaction with formaldehyde/acetaldehyde and the corresponding aromatic/heteroaromatic amines produces $\mathrm{N}^{1}$-aryl/heteroarylaminomethyl/ethyl-1,2,4-triazoles (Fig. 1), which have not been investigated previously. These compounds are of considerable synthetic interest as substances with potential biological activity. For that purpose substituted aromatic and heteroromatic amines have been chosen and special attention paid to the electron deficient heterocyclic amines. Reactions of 1-hydroxymethyl-1H-1,2,4-triazole with a number of aromatic/heteroaromatic amines in ethanol gave $\mathrm{N}^{1}$-aryl/heteroaryaminoethyl-1,2,4triazoles $(1-9,11-16)$ in a pure state according to the route I presented in Scheme I. In order to achieve this product, it was first necessary to convert the starting material $(1 \mathrm{H}-1,2,4$-triazole $)$ to the corresponding 1-hydroxymethyl-1H-1,2,4-triazole. The 1-hydroxymetyl-1H-1,2,4-triazole $(\mathrm{mp}=65$ $67{ }^{\circ} \mathrm{C}$ ) is produced by the reaction of paraformaldehyde ("in situ" source of formaldehyde), $1 \mathrm{H}$ 1,2,4-triazole and catalytic amount of triethylamine. The structure of 1-hydroxymethyl-1H-1,2,4-triazole was established by IR and ${ }^{1} \mathrm{H}$ NMR spectra.

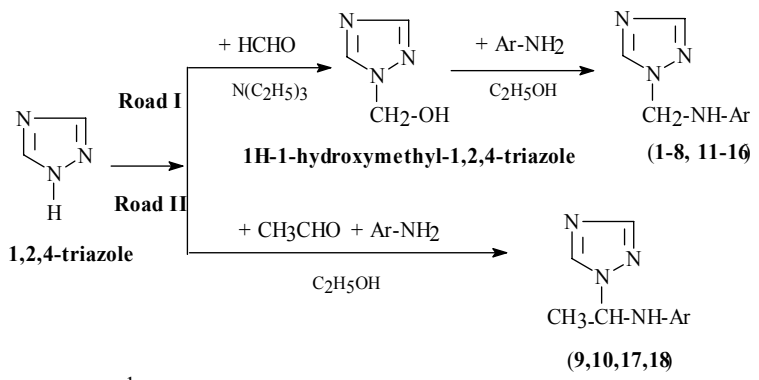

Fig. 1. $\mathrm{N}^{1}$-aryl/heteroarylaminomethyl/ethyl-1,2,4-triazoles $(1-18)$

When 1-hydroxymethyl-1H-1,2,4-triazole reacts with aromatic amines such as benzocaine; $o$ - and $p$-aminobenzoic acids; $p$-chloro- and $p$-bromoaniline; $p$-toluidine; $p$-aminobiphenyl and $p$-phenylenediamine, $\quad \mathrm{N}^{1}$-arylaminomethyl-1,2,4-triazoles are produced (1-8). 1-Hydroxymethyl-1H-1,2,4-triazole was used as starting material once again for the heteroaromatic amines: 2-amino-, 4-methyl-2-amino-, 6methyl-2-amino-, 6-chloro-2-aminopyridine and 4amino-1,2,4-triazole, and $\mathrm{N}^{1}$-heteroarylaminomethyl1,2,4-triazoles were obtained (11-16). The melting points, time of reaction, yield and elemental analysis of those compounds are given in Table1.

Acetaldehyde can also be used successfully as starting material for the condensation of 1,2,4triazole and aromatic/heteroaromatic amines (Fig. 1, route II). $\mathrm{N}^{1}$-aryl/heteroarylaminoethyl-1,2,4triazoles $(9,10,17,18)$ were obtained in good yield (Table 1) by mild heating of equimolar quantity of $1 \mathrm{H}-1,2,4-$ triazole, acetaldehyde and amines: benzocaine, $p$-nitroaniline; 2-amino-6-methylpyridine and 2-aminothiazole. The structures of the new aminomethyl/ethyl-1,2,4-triazole derivatives were confirmed by their IR, ${ }^{1} \mathrm{H}$ NMR and UV spectra [23]. 
Table 1

$N^{l}$-aryl/heteroarylaminomethyl/ethyl-1,2,4-triazole derivatives (1-18) used in the present study

\begin{tabular}{|c|c|c|c|c|c|c|c|}
\hline \multirow[t]{2}{*}{ Comp. } & \multirow[t]{2}{*}{$\mathrm{R}$} & \multirow{2}{*}{$\mathrm{Ar}$} & \multirow{2}{*}{$\begin{array}{l}\text { Mol. for. / (mol. wt.) } \\
\text { (g/mol) }\end{array}$} & \multirow{2}{*}{$\begin{array}{l}\mathrm{mp} \\
\left({ }^{0} \mathrm{C}\right)\end{array}$} & \multicolumn{3}{|c|}{$\begin{array}{c}\text { Elem. analysis cal./found } \\
(\%)\end{array}$} \\
\hline & & & & & $\mathrm{C}$ & $\mathrm{H}$ & $\mathrm{N}$ \\
\hline 1 & $\mathrm{H}$ & $-\mathrm{C}_{6} \mathrm{H}_{4}-\mathrm{COOC}_{2} \mathrm{H}_{5}(\mathrm{p})$ & $\mathrm{C}_{12} \mathrm{H}_{14} \mathrm{~N}_{4} \mathrm{O}_{2} / 246.27$ & $129-130$ & $\begin{array}{l}58.52 \\
58.02\end{array}$ & $\begin{array}{l}5.73 \\
5.13\end{array}$ & $\begin{array}{l}22.76 \\
22.20\end{array}$ \\
\hline 2 & $\mathrm{H}$ & $-\mathrm{C}_{6} \mathrm{H}_{4}-\mathrm{COOH}(\mathrm{p})$ & $\mathrm{C}_{10} \mathrm{H}_{10} \mathrm{~N}_{4} \mathrm{O}_{2} / 218.21$ & $185-186$ & $\begin{array}{r}55.04 \\
54.18\end{array}$ & $\begin{array}{l}4.62 \\
5.39\end{array}$ & $\begin{array}{l}25.67 \\
24.80\end{array}$ \\
\hline 3 & $\mathrm{H}$ & $-\mathrm{C}_{6} \mathrm{H}_{4}-\mathrm{COOH}(\mathrm{o})$ & $\mathrm{C}_{10} \mathrm{H}_{10} \mathrm{~N}_{4} \mathrm{O}_{2} / 218.21$ & $170-171$ & $\begin{array}{l}55.04 \\
54.57\end{array}$ & $\begin{array}{l}4.62 \\
5.19\end{array}$ & $\begin{array}{l}25.67 \\
25.10\end{array}$ \\
\hline 4 & $\mathrm{H}$ & $-\mathrm{C}_{6} \mathrm{H}_{4}-\mathrm{Cl}(\mathrm{p})$ & $\mathrm{C}_{9} \mathrm{H}_{9} \mathrm{~N}_{4} \mathrm{Cl} / 208.65$ & $89-91$ & $\begin{array}{l}51.81 \\
51.22\end{array}$ & $\begin{array}{l}4.35 \\
4.41\end{array}$ & $\begin{array}{l}26.85 \\
25.60\end{array}$ \\
\hline 5 & $\mathrm{H}$ & $-\mathrm{C}_{6} \mathrm{H}_{4}-\mathrm{Br}(\mathrm{p})$ & $\mathrm{C}_{9} \mathrm{H}_{9} \mathrm{~N}_{4} \mathrm{Br} / 253.11$ & $66-68$ & $\begin{array}{l}42.70 \\
41.71\end{array}$ & $\begin{array}{l}3.58 \\
4.41\end{array}$ & $\begin{array}{l}22.14 \\
22.48\end{array}$ \\
\hline 6 & $\mathrm{H}$ & $-\mathrm{C}_{6} \mathrm{H}_{4}-\mathrm{CH}_{3}(\mathrm{p})$ & $\mathrm{C}_{10} \mathrm{H}_{12} \mathrm{~N}_{4} / 88.23$ & $64-66$ & $\begin{array}{l}63.81 \\
62.96\end{array}$ & $\begin{array}{l}6.43 \\
6.30\end{array}$ & $\begin{array}{l}29.77 \\
29.35\end{array}$ \\
\hline 7 & $\mathrm{H}$ & $-\mathrm{C}_{6} \mathrm{H}_{4}-\mathrm{C}_{6} \mathrm{H}_{5}(\mathrm{p})$ & $\mathrm{C}_{15} \mathrm{H}_{14} \mathrm{~N}_{4} / 250.30$ & $124-125$ & $\begin{array}{l}71.97 \\
71.45\end{array}$ & $\begin{array}{l}5.64 \\
6.10\end{array}$ & $\begin{array}{l}22.38 \\
22.69\end{array}$ \\
\hline 8 & $\mathrm{H}$ & $-\mathrm{C}_{6} \mathrm{~N}_{4}-\mathrm{NH}-\mathrm{CH}_{2}-\mathrm{N}$ & $\mathrm{C}_{12} \mathrm{H}_{14} \mathrm{~N}_{8} / 270.30$ & $150-151$ & $\begin{array}{l}53.32 \\
52.98\end{array}$ & $\begin{array}{l}5.22 \\
5.24\end{array}$ & $\begin{array}{l}41.46 \\
40.79\end{array}$ \\
\hline 9 & $\mathrm{CH}_{3}$ & $-\mathrm{C}_{6} \mathrm{H}_{4}-\mathrm{COOC}_{2} \mathrm{H}_{5}(\mathrm{p})$ & $\mathrm{C}_{13} \mathrm{H}_{16} \mathrm{~N}_{4} \mathrm{O}_{2} / 260.29$ & $134-136$ & $\begin{array}{l}59.98 \\
59.45\end{array}$ & $\begin{array}{l}6.19 \\
6.41\end{array}$ & $\begin{array}{l}21.53 \\
22.07\end{array}$ \\
\hline 10 & $\mathrm{CH}_{3}$ & $-\mathrm{C}_{6} \mathrm{H}_{4}-\mathrm{NO}_{2}(\mathrm{p})$ & $\mathrm{C}_{10} \mathrm{H}_{11} \mathrm{~N}_{5} \mathrm{O}_{2} / 233.237$ & $149-150$ & $\begin{array}{l}51.50 \\
51.80\end{array}$ & $\begin{array}{l}4.75 \\
5.15\end{array}$ & $\begin{array}{l}30.03 \\
29.81\end{array}$ \\
\hline 11 & $\mathrm{H}$ & 2-Pyridyl- & $\mathrm{C}_{8} \mathrm{H}_{9} \mathrm{~N}_{5} / 175.19$ & $100-102$ & $\begin{array}{l}54.85 \\
53.90\end{array}$ & $\begin{array}{l}5.18 \\
5.11\end{array}$ & $\begin{array}{l}39.98 \\
39.38\end{array}$ \\
\hline 12 & $\mathrm{H}$ & 4-Methyl-2- pyridyl - & $\mathrm{C}_{9} \mathrm{H}_{11} \mathrm{~N}_{5} / 185.21$ & 108-109 & $\begin{array}{l}57.13 \\
56.93\end{array}$ & $\begin{array}{l}5.86 \\
6.37\end{array}$ & $\begin{array}{l}37.01 \\
38.03\end{array}$ \\
\hline 13 & $\mathrm{H}$ & 6- Methyl-2- pyridyl - & $\mathrm{C}_{9} \mathrm{H}_{11} \mathrm{~N}_{5} / 185.21$ & $94-95$ & $\begin{array}{l}57.14 \\
56.93\end{array}$ & $\begin{array}{l}5.86 \\
6.25\end{array}$ & $\begin{array}{l}37.01 \\
36.76\end{array}$ \\
\hline 14 & $\mathrm{H}$ & 5-Chloro-2-pyridyl- & $\mathrm{C}_{8} \mathrm{H}_{8} \mathrm{~N}_{5} \mathrm{Cl} / 206.61$ & $153-155$ & $\begin{array}{l}46.59 \\
46.05\end{array}$ & $\begin{array}{l}3.91 \\
3.98\end{array}$ & $\begin{array}{l}33.96 \\
33.15\end{array}$ \\
\hline 15 & $\mathrm{H}$ & 2-Pyrimidyl- & $\mathrm{C}_{7} \mathrm{H}_{8} \mathrm{~N}_{6} / 176.18$ & $149-150$ & $\begin{array}{l}47.72 \\
47.47\end{array}$ & $\begin{array}{l}4.58 \\
4.93\end{array}$ & $\begin{array}{l}47.70 \\
47.98\end{array}$ \\
\hline 16 & $\mathrm{H}$ & 1,2,4-Triazole-4-yl & $\mathrm{C}_{5} \mathrm{H}_{7} \mathrm{~N}_{7} / 165.16$ & 123 & $\begin{array}{l}36.36 \\
36.40\end{array}$ & $\begin{array}{l}4.27 \\
4.63\end{array}$ & $\begin{array}{l}59.36 \\
58.67\end{array}$ \\
\hline 17 & $\mathrm{CH}_{3}$ & 6-Methyl-2-pyridyl- & $\mathrm{C}_{10} \mathrm{H}_{13} \mathrm{~N}_{5} / 203.25$ & 136 & $\begin{array}{l}59.10 \\
59.77\end{array}$ & $\begin{array}{l}6.45 \\
5.95\end{array}$ & $\begin{array}{l}34.56 \\
33.87\end{array}$ \\
\hline 18 & $\mathrm{CH}_{3}$ & 2-Thiazolyl- & $\mathrm{C}_{7} \mathrm{H}_{9} \mathrm{~N}_{5} \mathrm{~S} / 195.25$ & $171-172$ & $\begin{array}{l}43.06 \\
42.22\end{array}$ & $\begin{array}{l}4.65 \\
4.67\end{array}$ & $\begin{array}{l}35.87 \\
35.78\end{array}$ \\
\hline
\end{tabular}

\section{Microbiology}

The filter paper disc method [27] was performed in Mueller Hinton agar. These agar media were inoculated with $0.5 \mathrm{~mL}$ of the $24 \mathrm{~h}$ liquid cultures containing $10^{7}$ microorganisms $/ \mathrm{mL}$. Filter paper discs (5 $\mathrm{mm}$ diameter) saturated with each compound solution $(1 \mathrm{mg} / \mathrm{mL} ; 5 \mathrm{mg} / \mathrm{mL}$ and 10 $\mathrm{mg} / \mathrm{mL}$ in DMSO) were placed on the indicated agar media. The plates were incubated at $37^{\circ} \mathrm{C}$ for $24 \mathrm{~h}$. Discs with DMSO were used as control. The diameter of zone inhibition [mm] was measured. The tests were repeated 3 times to confirm the findings. 
In our work, the chosen model is based on the in vitro antimicrobial activity of certain $\mathrm{N}^{1}$ aryl/heteroarylaminomethyl/ethyl-1,2,4-triazoles derivatives (1-18) (Fig. 1) against Bacillus subtilis and Salmonella enteritidis, expressed as zone of

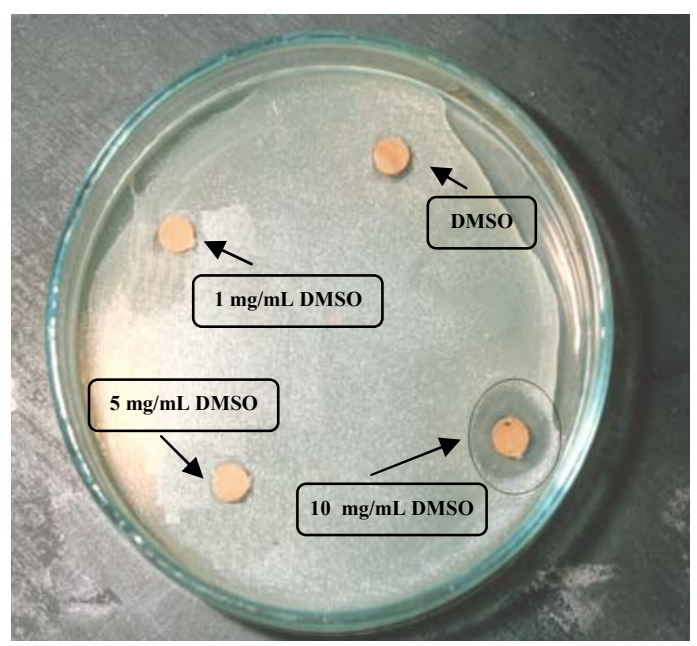

Fig. 2. Filter paper discs saturated with compound (16) solution ( $1 \mathrm{mg} / \mathrm{mL} ; 5 \mathrm{mg} / \mathrm{mL}$ and $10 \mathrm{mg} / \mathrm{mL}$ in DMSO) inhibition [mm], using 3 concentrations: $1 \mathrm{mg} / \mathrm{mL}$, $5 \mathrm{mg} / \mathrm{mL}$ and $10 \mathrm{mg} / \mathrm{mL}$ in DMSO (Table 2). C is the minimum inhibition concentration (MIC) value expressed in molar concentration units (Table 2).

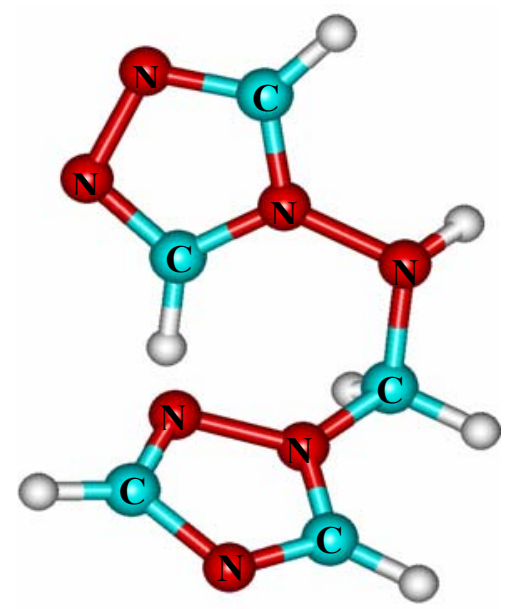

Fig. 3. The most active compound (16) against Bacillus subtilis

Table 2

Experimental zone of inhibition [mm] obtained against: B. subtilis and S. enteritidis and calculated $\log 1 / C$ values

\begin{tabular}{|c|c|c|c|c|c|c|c|c|c|c|}
\hline \multirow{3}{*}{$\begin{array}{l}\text { Comp. } \\
\text { No: }\end{array}$} & \multicolumn{5}{|c|}{ Bacillus subtilis } & \multicolumn{5}{|c|}{ Salmonella enteritidis } \\
\hline & \multicolumn{3}{|c|}{ Zone of inhibition [mm] } & \multirow{2}{*}{$\begin{array}{c}\mathrm{MIC}^{\mathrm{a}} \\
(\mathrm{mol} / \mathrm{mL})\end{array}$} & \multirow[b]{2}{*}{$\log 1 / \mathrm{C}$} & \multicolumn{3}{|c|}{ Zone of inhibition [mm] } & \multirow{2}{*}{$\begin{array}{c}\mathrm{MIC}^{\mathrm{a}} \\
(\mathrm{mol} / \mathrm{mL})\end{array}$} & \multirow[b]{2}{*}{$\log 1 / \mathrm{C}$} \\
\hline & $\begin{array}{c}1 \\
(\mathrm{mg} / \mathrm{mL})^{\mathrm{b}}\end{array}$ & $\begin{array}{c}5 \\
(\mathrm{mg} / \mathrm{mL})^{\mathrm{b}}\end{array}$ & $\begin{array}{c}10 \\
(\mathrm{mg} / \mathrm{mL})^{\mathrm{b}}\end{array}$ & & & $\begin{array}{c}1 \\
(\mathrm{mg} / \mathrm{mL})^{\mathrm{b}}\end{array}$ & $\begin{array}{c}5 \\
(\mathrm{mg} / \mathrm{mL})^{\mathrm{b}}\end{array}$ & $\begin{array}{c}10 \\
(\mathrm{mg} / \mathrm{mL})^{\mathrm{b}}\end{array}$ & & \\
\hline 1 & 6 & 6 & 6 & $4.061 \mathrm{E}-6$ & 5.391 & 6 & 7.5 & 9.5 & $4.061 \mathrm{E}-6$ & 5.391 \\
\hline 2 & - & 6 & 6 & $2.291 \mathrm{E}-5$ & 4.639 & 6 & 6 & 6.5 & $4.583 \mathrm{E}-6$ & 5.339 \\
\hline 3 & - & - & - & - & - & - & - & - & - & - \\
\hline 4 & - & - & 6 & $4.793 \mathrm{E}-5$ & 4.319 & 6 & 6 & 6.5 & $4.793 \mathrm{E}-6$ & 5.319 \\
\hline 5 & - & 5.5 & 6 & $1.975 \mathrm{E}-5$ & 4.704 & 5.5 & 5.5 & 6 & $3.951 \mathrm{E}-6$ & 5.403 \\
\hline 6 & - & 6 & 6.5 & $2.656 \mathrm{E}-5$ & 4.575 & - & 6 & 7.5 & $2.656 \mathrm{E}-5$ & 4.576 \\
\hline 7 & 5.5 & 5.5 & 5.5 & $3.995 \mathrm{E}-6$ & 5.398 & - & 6 & 6 & $1.998 \mathrm{E}-5$ & 4.699 \\
\hline 8 & - & - & - & - & - & - & - & 6 & $3.842 \mathrm{E}-5$ & 4.415 \\
\hline 9 & - & - & 6 & $3.842 \mathrm{E}-5$ & 4.415 & - & 7 & 7 & $1.921 \mathrm{E}-5$ & 4.716 \\
\hline 10 & - & - & 5.5 & $4.287 \mathrm{E}-5$ & 4.367 & - & - & - & - & - \\
\hline 11 & - & - & 7.5 & $5.708 \mathrm{E}-5$ & 4.244 & 6 & 6 & 6.5 & $5.708 \mathrm{E}-6$ & 5.244 \\
\hline 12 & - & - & - & - & - & 5.5 & 6 & 6 & $5.399 \mathrm{E}-6$ & 5.267 \\
\hline 13 & - & - & 5.5 & $5.399 \mathrm{E}-5$ & 4.267 & - & - & 7.5 & $5.399 \mathrm{E}-5$ & 4.267 \\
\hline 14 & - & - & - & - & - & - & - & - & - & - \\
\hline 15 & - & - & - & - & - & - & - & - & - & - \\
\hline 16 & - & - & 8 & $6.055 \mathrm{E}-5$ & 4.217 & 6 & 6 & 7 & $6.055 \mathrm{E}-6$ & 5.218 \\
\hline 17 & - & - & - & - & - & - & - & - & - & - \\
\hline 18 & - & - & - & - & - & - & - & - & - & - \\
\hline
\end{tabular}

${ }^{a}$ minimum inhibition concentration; ${ }^{b}$ solutions: 1,5 and $10 \mathrm{mg} / \mathrm{mL}$ in DMSO 


\section{QSAR analysis}

\section{A. Descriptors}

To obtain the quantitative effect of structural parameters of the triazole derivatives on their biological activities, QSAR analysis with physicochemical descriptors was performed. The Surface Tension (ST), Molar Refraction (MR), Molar
Volumen (MV), Parachor (Pc), Index of Refractivity $(\eta)$; Density (D), Polarizability $(\alpha)$ and $\log P$, are the properties that can be calculated for each molecule. Therefore, these data were used to determine the QSAR models. The physicochemical parameters used in this study were calculated using ACD Labs software [28].

Table 3

Physicochemical parameters of triazole derivatives studied

\begin{tabular}{ccccccccc}
\hline \hline Comp. & $\mathrm{MR}^{a}$ & $\mathrm{MV}^{a}$ & $\mathrm{Pc}^{a}$ & $\eta^{a}$ & $\mathrm{ST}^{a}$ & $\mathrm{D}^{a}$ & $\alpha^{a}$ & $\log \mathrm{P}^{b}$ \\
\hline 1 & 67.92 & 196.6 & 518.7 & 1.607 & 48.4 & 1.25 & 26.29 & 1.2981 \\
2 & 58.35 & 156.0 & 435.5 & 1.670 & 60.6 & 1.39 & 23.13 & 0.4579 \\
3 & 58.35 & 156.0 & 435.5 & 1.670 & 60.6 & 1.39 & 23.13 & 1.4690 \\
4 & 56.64 & 154.6 & 414.4 & 1.653 & 51.5 & 1.34 & 22.45 & 1.2210 \\
5 & 59.59 & 157.9 & 429.1 & 1.678 & 54.5 & 1.60 & 23.62 & 1.4665 \\
6 & 56.46 & 160.5 & 416.7 & 1.620 & 45.3 & 1.17 & 22.38 & 1.1238 \\
7 & 77.14 & 213.4 & 562.5 & 1.642 & 48.1 & 1.17 & 30.58 & 2.3405 \\
8 & 76.43 & 190.1 & 540.0 & 1.736 & 65.0 & 1.42 & 30.30 & -1.6900 \\
9 & 72.34 & 211.8 & 549.8 & 1.598 & 45.3 & 1.22 & 28.68 & 1.7157 \\
10 & 62.12 & 166.0 & 462.2 & 1.671 & 60.0 & 1.40 & 24.62 & 1.3895 \\
11 & 50.48 & 133.9 & 366.7 & 1.677 & 56.2 & 1.30 & 20.01 & 0.0301 \\
12 & 54.90 & 149.2 & 397.8 & 1.657 & 50.5 & 1.26 & 21.76 & 0.5774 \\
13 & 54.90 & 149.2 & 397.8 & 1.657 & 50.5 & 1.26 & 21.76 & 0.5774 \\
14 & 55.08 & 143.2 & 395.6 & 1.695 & 58.1 & 1.46 & 21.83 & 0.6746 \\
15 & 48.93 & 122.5 & 347.9 & 1.730 & 64.9 & 1.43 & 19.39 & -1.4763 \\
16 & 43.66 & 101.1 & 304.8 & 1.811 & 82.5 & 1.63 & 17.31 & 2.1800 \\
17 & 59.33 & 164.4 & 428.9 & 1.641 & 46.2 & 1.23 & 23.52 & 0.9950 \\
18 & 53.50 & 131.1 & 370.0 & 1.748 & 62.8 & 1.48 & 21.21 & 0.7441 \\
\hline \hline
\end{tabular}

$\left({ }^{\mathrm{a}}\right.$ Ref. [28]; ${ }^{\mathrm{b}}$ Ref. [29])

Surface tension (ST) or Inter facial tension is the cumulative effect of the different intra- and intermolecular forces of two different surfaces. This physicochemical parameter is directly related to the parachor $(\mathrm{Pc})$ which in turn is related to the molar volume (MV). Thus, we can treat (ST) as a steric parameter. The relationships between (MV), (Pc) and (ST) could be only expressed through the expression for parameter. These three forms are expressed by following equations (Eq. 1-3):

$$
\begin{gathered}
\text { Molar Volume }=M V=M W / d \\
\qquad P c=(M W / d) S T^{1 / 4} \\
\text { Surface Tension }=S T=(P c / M V)^{4}
\end{gathered}
$$

Molar Refractivity (MR) is one of the oldest and most successful additive - constitutive phys- icochemical properties of a compound, which has a strong correlation with the molecular polarizability. Thus, the MR is known to be a measure of the polarizability and is calculated by the well-documented Lorentz-Lorenz equation [30].

The Polarizability $(\alpha)$ of a molecule is also in the focus of our research. The electrons and nuclei of a molecule are mobile and free to move to a limited degree. Thus, small charge displacements can take place in polar or non-polar (apolar) molecules in an electric field, and results in a dipole being introduced into the molecule, in addition to the permanent one that may already exist. Thus, the polarizability of a molecule is a measure of its overall electronic charge distribution that can be distorted by an external electric field [30]. 
The most common descriptor used in QSAR studies is $\log \mathrm{P}$, which is the natural $\log$ of the octanol/water partition coefficient (Eq. 4):

$$
\log P=\log [\text { drug }]_{\text {octanol }}-\log [\text { drug }]_{\text {water }}
$$

The octanol/water partition coefficient is a measure of the hydrophobic-hydrophilic character of the compound and it is measured by placing the compound in a separatory funnel with octanol and water. Octanol and water are immiscible, and the compound under study partitions between the two phases. The concentration of the compound in each phase is calculated and their ratio gives the partition coefficient. The more hydrophobic the compound is, the larger $P$ is, and $\log P$ shows the compound to be apolar. $\log P$ is a common descriptor in QSAR studies because drugs must often cross membranes. Cell membranes are composed of phospholipids, which have hydrophobic tails which produce a very hydrophobic environment in the middle of the lipid bilayer. Without active transport through the membrane, more hydrophobic drugs pass more readily through a membrane.

\section{B. Multiple linear regression}

The mathematical foundation of the quantitative structure - activity relationship is based on the principle of polylinearity. Multiple linear regression is a common method used in QSAR studies. The QSAR equations were obtained by forward stepwise multiple regression techniques - the multilinear forms (Eq. 5):

$$
\log 1 / C=a_{0}+a_{1} D_{1}+a_{2} D_{2}+a_{3} D_{3}+\ldots .+a_{\mathrm{n}} D_{n}
$$

where $D_{1}, D_{2}, D_{3}$ and $D_{n}$ are descriptors, $n$ is number of descriptors. The intercept $\left(a_{0}\right)$ and regression coefficient of the descriptors were determined using the least squares method.

\section{Statistical analysis}

The statistical evaluation of the data was performed using Origin program package [31]. To test the quality of the regression equations, the following statistical parameters were used:

o $\mathrm{R}$ - correlation coefficient;

o SD - standard deviation;

o F-test -Fisher test for significance of the equation;

- PRESS - Predictive Residual Error Sum of Squares PRESS $=\Sigma\left(Y_{\text {pred }}-Y_{\text {exp }}\right)^{2}$; o SSY - Sum of squares of deviation of the experimental values from their mean $\mathrm{SSY}=\Sigma\left(Y_{\exp }-Y_{\text {mean }}\right)^{2}$, where $Y_{\text {pred }}-$ predicted, $Y_{\text {exp }}-$ experimental and $Y_{\text {mean }}-$ mean values of the target properties $(\log 1 / \mathrm{C})$, respectively.

o $\mathrm{Q}^{2}$ - Cross-validation squared correlation coefficient

\section{RESULTS AND DISCUSSION}

In the earlier times of QSAR study on 1,2,4triazoles were mostly based on the Hansch's approach. In our previous study [32, 33], we have shown that some electronic and steric descriptors can be used for this purpose with successful outcome. No QSAR study for $\mathrm{N}^{1}$-aryl/heteroarylaminomethyl/ethyl-1,2,4-triazole derivatives using physicochemical properties such as Surface Tension (ST), Molar Refraction (MR), Molar Volume (MV), Parachor (Pc), Index of Refractivity $(\eta)$; Density (D) and Polarizability $(\alpha)$ has been reported in the literature.

In view of this and in line with our earlier work, in the present study an attempt was made to find the structural requirements for inhibition of different bacterial strains by 1,2,4-triazole derivatives using the QSAR approach with several steric and one hydrophobic descriptor. The statistical quality of the regression equation was justified by parameters such as: R; SD; F-test; $\mathrm{Q}^{2}$, PRESS, SSY and PRESS/SSY.

After application of the filter paper disc method [27], compounds 14, 15, 17 and 18 did not show growth inhibition of the chosen microorganisms [23]. From the data obtained, MIC values were calculated first and then the $\log 1 / \mathrm{C}$ values (Table 2).

\section{QSAR study for antibacterial activity of Bacillus subtilis}

It was important for further analysis to develop a correlation matrix for the descriptors utilized and their correlations with the biological activities (Table 4). The results (Tab. 4) show that some of the descriptors are mutually correlated. Thus, if a combination of them is present in the regression expression, then the model may suffer from a defect due to collinearly. A perusal of Ta- 
ble 4 shows that all chosen descriptors are not well correlated with antibacterial activity; meaning that in mono-parametric regressions, those properties are not appropriate to obtain statistically significant results.

All physicochemical descriptors (Table 3) were selected as independent variables and $\log 1 / \mathrm{C}$ as dependent values, and the stepwise multiple linear regression method was used resulting in the following equations (Table 5). Among the several models generated, the six best were selected for the discussion. The selection was based on the previously mentioned statistical parameters. The statistically significant results for growth inhibition activity of triazole derivatives against Bacillus subtilis, using five to eight descriptors, have been summarized in Table 5.

Table 4

Correlation matrix for the chosen parameters (Bacillus subtilis)

\begin{tabular}{|c|c|c|c|c|c|c|c|c|c|}
\hline & $\log 1 / C$ & MR & MV & Pc & $\eta$ & ST & D & $\alpha$ & $\log P$ \\
\hline $\log 1 / C$ & 1.0000 & & & & & & & & \\
\hline MR & 0.7165 & 1.0000 & & & & & & & \\
\hline MV & 0.6847 & 0.9623 & 1.0000 & & & & & & \\
\hline Pc & 0.7001 & 0.9893 & 0.9853 & 1.0000 & & & & & \\
\hline$\eta$ & -0.4322 & -0.4720 & -0.6806 & -0.5652 & 1.0000 & & & & \\
\hline ST & -0.4006 & -0.4542 & -0.6418 & -0.5139 & 0.9492 & 1.0000 & & & \\
\hline D & -0.3512 & -0.4274 & -0.5853 & -0.4816 & 0.7913 & 0.8049 & 1.0000 & & \\
\hline$\alpha$ & 0.6940 & 0.9992 & 0.9575 & 0.9856 & -0.4619 & -0.4486 & -0.4522 & 1.0000 & \\
\hline $\log P$ & 0.3655 & -0.1283 & 0.0086 & -0.0624 & -0.1709 & -0.0827 & 0.0066 & -0.1330 & 1.0000 \\
\hline
\end{tabular}

Table 5

Regression parameters and the quality of correlation of $\log 1 / C$ with chosen descriptors in multivariate regressions for substituted 1,2,4-triazoles (Bacillus subtilis)

(6) $\log 1 / \mathrm{C}=155.40629+2.53222 \mathrm{MR}+0.22519 \mathrm{MV}-0.30603 \mathrm{Pc}-112.07019 \eta+0.57547 \mathrm{ST}+1.29012 \mathrm{D}-2.15043 \alpha-0.28864 \log \mathrm{P}$ $\mathrm{R}=0.9978 \quad \mathrm{SD}=0.0448 \quad \mathrm{~F}=113.3163$

(7) $\quad \log 1 / \mathrm{C}=129.1383+2.1564 \mathrm{MR}+0.1309 \mathrm{MV}-0.2281 \mathrm{Pc}-90.7614 \eta+0.4355 \mathrm{ST}+0.6005 \mathrm{D}-2.0405 \alpha$ $\mathrm{R}=0.9840 \quad \mathrm{SD}=0.1389 \quad \mathrm{~F}=13.0867$

(8) $\log 1 / \mathrm{C}=-55.0376-0.1086 \mathrm{MV}+0.0993 \mathrm{Pc}+42.47831 \eta-0.2218 \mathrm{ST}-0.9775 \mathrm{D}-1.0002 \alpha+0.1106 \log \mathrm{P}$

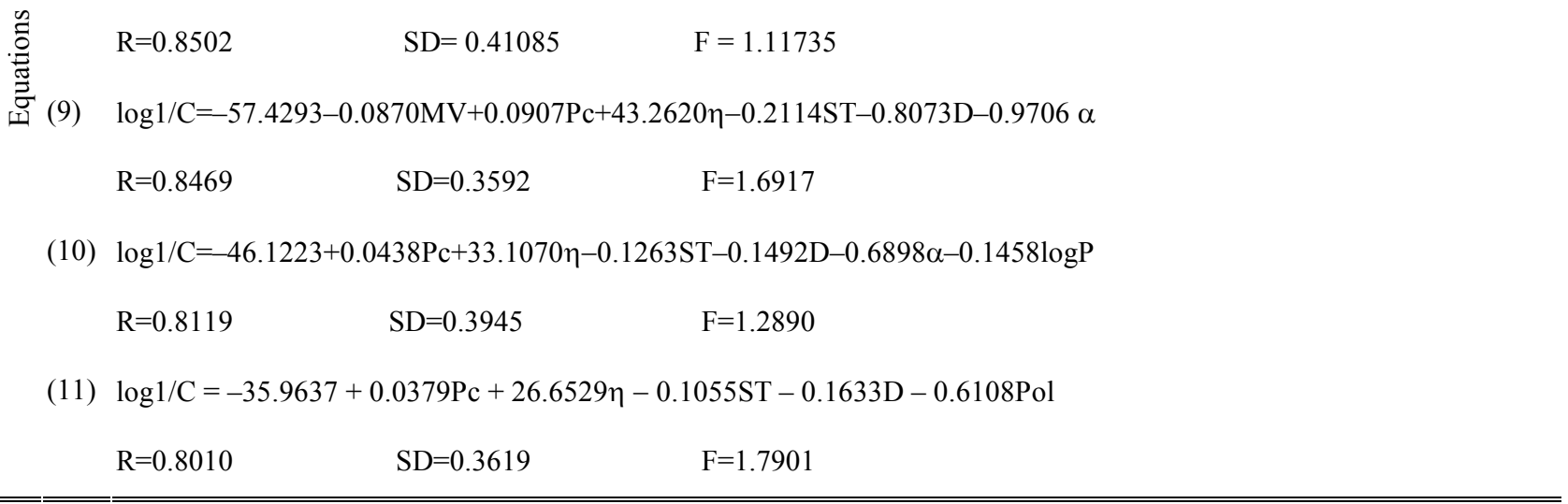


Initial regression analysis indicated that out of the eight molecular descriptors used, in combination with other physicochemical descriptors, $\eta$ plays a dominant role in shaping antibacterial activity (the greatest value of regression coefficient of the $\eta$ ). The positive coefficients of $\eta$ indicates that the activity increases as the magnitude of those descriptors increases (Eq. 8-11).

The correlation coefficients were found to be good (0.80-0.99) in all cases and the standard deviations were below 0.42 (Table 5). An excellent correlation was obtained in Eq. 6, where the correlation coefficient is positive with a $R$ value of 0.9978 and SD 0.0448 .

\subsection{Validation}

We have undertaken a cross-validation methodology for deciding the predictive power of the proposed models (Eq. $6-11$ ). This was needed because a model with good statistics may not have good predictive potential. The various crossvalidation parameters, calculated for the proposed models, are presented in Table 6 and are discussed below.

The predictivity of each model was measured by the cross-validated regression coefficient $\left(Q^{2}\right)$ defined as:

$$
Q^{2}=1-\Sigma\left(Y_{\text {pred }}-Y_{\exp }\right)^{2} / \Sigma\left(Y_{\text {exp }}-Y_{\text {mean }}\right)^{2}
$$

where $Y_{\text {pred }}$ - predicted, $Y_{\text {exp }}-$ experimental, and $Y_{\text {mean }}$ - mean values of the target properties $(\log 1 / \mathrm{C})$ respectively. The calculated $Q^{2}$ values are presented in Table 6, together with PRESS and PRESS/SSY values.
Good cross-validation $Q^{2}$ values were obtained for models $(6-11)\left(Q^{2}>0.72 ; Q^{2}=0.831-\right.$ 0.998) suggesting that the models are useful tool for predicting the inhibition of Bacillus subtilis.

PRESS appears to be an important crossvalidation parameter accounting for a good estimate of the real predictive error of the model. When its value is less than SSY, the model predicts better than by chance alone, and can be considered statistically significant. In our case (Table 6) PRESS $<<$ SSY indicating that all models obtained are statistically significant and are better that chance.

For the QSAR model to be considered reasonable, PRESS/SSY should be smaller than 0.4 and the data presented in Table 6 indicate that all models proposed are significant. In our case the ratio PRESS/SSY ranges between 0.002-0.169 indicating that all proposed models are reliable QSAR models.

Finally, in order to confirm our findings, antimicrobial activity against Bacillus subtilis (log 1/C) predicted by Eq. (6), (7), (8), (9), (10) and (11) were compared with the corresponding log $1 / \mathrm{C}$ values reported in Table 2 . These comparisons are shown in Table 7. The values agree well within experimental error. The residual, is the difference between observed and calculated $\log 1 / \mathrm{C}$.

A plot between the experimental and calculated $\log 1 / \mathrm{C}$ values is shown in Figure 4. Also, we calculated the predictive correlation coefficient $\left(R_{\text {pre }}\right)$, (Table 8$)$, by correlating the estimated $\log 1 / \mathrm{C}$ values with the experimental once. The obtained predictive correlation coefficient $\left(R_{\text {pre }}=0.8173 \div 0.9989\right)$ confirms our findings.

Table 6

Cross-validation parameters, calculated for the proposed models: $Q^{2}$, PRESS and PRESS/SSY

\begin{tabular}{clccc}
\hline Equation & Parameters & $\mathrm{Q}^{2}$ & PRESS & PRESS/SSY \\
\hline$(6)$ & MR, MV, Pc, $\eta, \mathrm{ST}, \mathrm{D}, \alpha, \log \mathrm{P}$ & 0.998 & 0.004 & 0.002 \\
$(7)$ & $\mathrm{MR}, \mathrm{MV}, \mathrm{Pc}, \eta, \mathrm{ST}, \mathrm{D}, \alpha$ & 0.981 & 0.058 & 0.019 \\
$(8)$ & $\mathrm{MV}, \mathrm{Pc}, \eta, \mathrm{ST}, \mathrm{D}, \alpha, \log \mathrm{P}$ & 0.831 & 0.506 & 0.169 \\
$(9)$ & $\mathrm{MV}, \mathrm{Pc}, \eta, \mathrm{ST}, \mathrm{D}, \alpha$ & 0.871 & 0.516 & 0.129 \\
$(10)$ & $\mathrm{Pc}, \eta, \mathrm{ST}, \mathrm{D}, \alpha, \log \mathrm{P}$ & 0.844 & 0.623 & 0.156 \\
$(11)$ & Pc,, , ST, D, $\alpha$, & 0.869 & 0.655 & 0.131 \\
\hline \hline
\end{tabular}


Table 7

Comparation of estimated $\log 1 / C$ values of $N^{1}$-aryl/heteroarylaminomethyl/ethyl-1,2,4-triazoles derivatives (1-18), with those reported in Table 2. (Residue = difference between observed and estimated $\log 1 / C$ ) (Bacillus subtilis)

\begin{tabular}{|c|c|c|c|c|c|c|c|c|c|c|c|c|c|}
\hline \multirow{3}{*}{ छे } & \multirow{3}{*}{$\log 1 / \mathrm{C}_{\exp }$} & \multicolumn{12}{|c|}{ Estimated $\log 1 / \mathrm{C}$} \\
\hline & & \multicolumn{2}{|c|}{ Equation (6) } & \multicolumn{2}{|c|}{ Equation (7) } & \multicolumn{2}{|c|}{ Equation (8) } & \multicolumn{2}{|c|}{ Equation (9) } & \multicolumn{2}{|c|}{ Equation (10) } & \multicolumn{2}{|c|}{ Equation (11) } \\
\hline & & $\log 1 / \mathrm{C}_{\text {eq. } 6}$ & Residue & $\log 1 / \mathrm{C}_{\text {eq. }} 7$ & Residue & $\log 1 / \mathrm{C}_{\text {eq. } 8}$ & Residue & $\log 1 / \mathrm{C}_{\text {eq. }}$. & Residue & $\log 1 / \mathrm{C}_{\text {eq. } 10}$ & Residue & $\log 1 / \mathrm{C}_{\text {eq. } .11}$ & Residue \\
\hline 1 & 5.391 & 5.388 & 0.003 & 5.351 & 0.040 & 5.266 & 0.125 & 5.277 & 0.114 & 5.176 & 0.215 & 5.158 & 0.233 \\
\hline 2 & 4.639 & 4.653 & -0.014 & 4.505 & 0.134 & 4.314 & 0.325 & 4.363 & 0.276 & 4.358 & 0.281 & 4.304 & 0.335 \\
\hline 4 & 4.319 & 4.311 & 0.008 & 4.384 & -0.065 & 4.481 & -0.162 & 4.460 & -0.141 & 4.386 & -0.067 & 4.435 & -0.116 \\
\hline 5 & 4.704 & 4.698 & 0.006 & 4.631 & 0.073 & 4.582 & 0.122 & 4.608 & 0.097 & 4.597 & 0.107 & 4.585 & 0.119 \\
\hline 7 & 5.398 & 5.390 & 0.008 & 5.332 & 0.066 & 5.246 & 0.152 & 5.266 & 0.132 & 5.192 & 0.206 & 5.175 & 0.223 \\
\hline 9 & 4.415 & 4.412 & 0.003 & 4.350 & 0.065 & 4.693 & -0.28 & 4.746 & -0.331 & 4.927 & -0.512 & 4.969 & -0.554 \\
\hline 10 & 4.367 & 4.363 & 0.004 & 4.467 & -0.100 & 4.658 & -0.291 & 4.631 & -0.264 & 4.472 & -0.105 & 4.494 & -0.127 \\
\hline 11 & 4.2435 & 4.203 & 0.041 & 4.095 & 0.148 & 4.318 & -0.074 & 4.380 & -0.136 & 4.360 & -0.117 & 4.268 & -0.024 \\
\hline 13 & 4.267 & 4.311 & -0.044 & 4.273 & -0.006 & 4.509 & -0.242 & 4.543 & -0.276 & 4.499 & -0.232 & 4.452 & -0.185 \\
\hline 16 & 4.217 & 4.219 & -0.002 & 4.213 & 0.004 & 4.207 & 0.100 & 4.210 & 0.007 & 4.263 & -0.046 & 4.314 & -0.097 \\
\hline
\end{tabular}

Table 8

Calculated predictive correlation coefficient $\left(R_{\text {pre }}{ }^{2}\right)$ for equations: (6); (7); (8); (9); (10) and (11)

\begin{tabular}{c|c|c|c}
\hline \hline Equation & Correlation: $\log 1 / \mathrm{C}_{\text {exp }}$ with $\log 1 / \mathrm{C}_{\text {eq. }}$ & $\begin{array}{c}\text { Predictive correlation } \\
\text { coefficient }\left(\mathrm{R}_{\text {pre }}\right)\end{array}$ & $\mathrm{SD}$ \\
\hline \hline$(6)$ & $\log 1 / \mathrm{C}_{\text {exp. }}=1.0008 \log 1 / \mathrm{C}_{\text {eq.(6) }}-0.0023$ & 0.9989 & 0.022 \\
$(7)$ & $\log 1 / \mathrm{C}_{\text {exp. }}=1.0109 \log 1 / \mathrm{C}_{\text {eq.(7) }}-0.0138$ & 0.9843 & 0.082 \\
$(8)$ & $\log 1 / \mathrm{C}_{\text {exp. }}=1.0922 \log 1 / \mathrm{C}_{\text {eq.(8) }}-0.4578$ & 0.8863 & 0.180 \\
$(9)$ & $\log 1 / \mathrm{C}_{\text {exp. }}=1.1124 \log 1 / \mathrm{C}_{\text {eq.(9) }}-0.5746$ & 0.8940 & 0.172 \\
$(10)$ & $\log 1 / \mathrm{C}_{\text {exp. }}=1.1025 \log 1 / \mathrm{C}_{\text {eq.(10) }}-0.5007$ & 0.8499 & 0.194 \\
$(11)$ & $\log 1 / \mathrm{C}_{\text {exp. }}=1.0461 \log 1 / \mathrm{C}_{\text {eq.(11) }}-0.2319$ & 0.8173 & 0.215 \\
\hline \hline
\end{tabular}

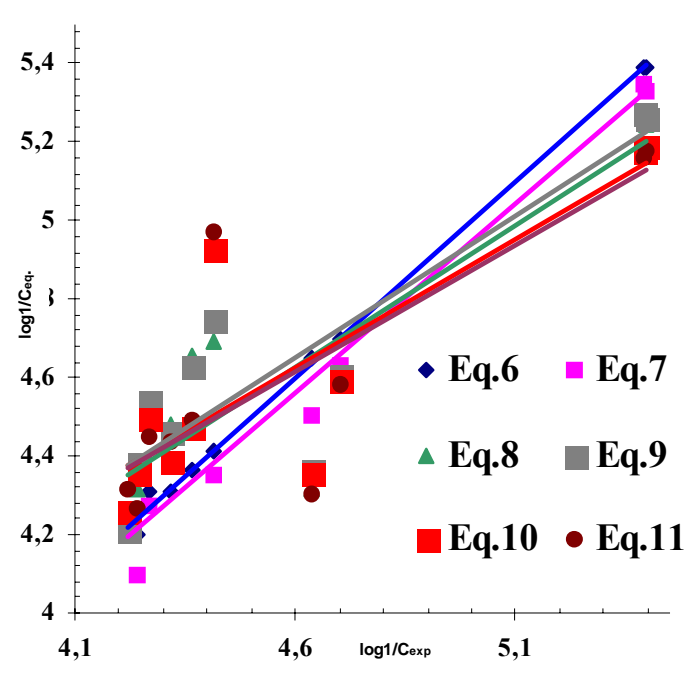

Fig.4. Plot of the experimental and calculated $\log 1 / \mathrm{C}$ values of compounds 1-18 against Bacillus subtilis

\section{QSAR study for antibacterial activity of Salmonella enteritidis}

No statistically significant results for inhibitory activity against Salmonella enteritidis bacteria with the chosen $\mathrm{N}^{1}$-aryl/heteroarylaminomethylethyl-1,2,4-triazole derivatives, using all eight descriptors, were obtained.

\section{CONCLUSION}

Spurred by the need of new antimicrobial agents and the fact that many effective drugs, insecticides and fungicides possess heterocyclic systems in their structure, such as the triazole ring, we synthesized several new 1,2,4-triazole derivatives. In view of the results and discussions above, we 
conclude that physicochemical properties such Surface Tension (ST), Molar Refraction (MR), Molar Volume (MV), Parachor (Pc), Index of Refractivity $(\eta)$, Density (D) and Polarizability $(\alpha)$ can successfully be used for modelling growth inhibition activity of triazole derivatives against $B a-$ cillus subtilis. These results will help medical as well as agricultural scientists in the design and prediction of compounds with increased activity and thus the synthesis of new triazoles exhibiting better activities then those reported in this paper.

\section{REFERENCES}

[1] http://www.chem.swin.edu.au/modules/mod4/index.html (last accessed: 01.04.2008)

[2] C. Hansch, A. Leo, Exploring QSAR: Fundamentals and Applications in Chemistry and Biology, American Chemical Society, Washington, DC, 1995.

[3] M. Karelson, V. Lobanov, A. Katritzky, QuantumChemical Descriptors in QSAR/QSPR Studies, Chem. Rev., 96, 1027-1043 (1996).

[4] M. Polyakova, L. Mei Jin, K. Ho Row, QSPR Models for Chromatographic Retention of some Azoles with Physicochemical properties, Bull. Korean Chem. Soc., 27, 211-218 (2006).

[5] J-L. Xu, S-L. Gao, X-F. Zhang, Y-P. Xie, X-Y. Huang, X-G. Xie, QSAR Studies on 7-Substituted Fluoroquinolones, Chinese J. Struct. Chem., 26, 91-97 (2007).

[6] P. Vasanthanathan, M. Lakshimi, M. Babu, A. Gupta, S. Kaskhedikar, QSAR Study of 3-Phenyl-5acyloxymethyl-2H,5H-furan-2-ones as Antifungal Agents, Vhem. Pharm. Bull., 54, 583-587 (2006).

[7] M. Tandon, J. P. Barthwal, T. N. Bhall, K P. Bhargava, Synthesis and Antiinflammatory Activity of Some New 3-(o-Substituted phenyl)-4-substituted-phenyl-5alkyl/alkenyl-mercapto-1H-1,2,4-triazoles, Indian $J$. Chem., 20B, 1017-1018 (1981).

[8] S. Rollas, Synthesis and Spectrometric Analysis of some 1,2,4-triazole-5-thiones, J. Fac. Pharm. Istanbul, 17, 155-163 (1981).

[9] B. N. Goswami, J. C. S. Kataky, J. N. Baruah, Synthesis and Antibaceterial Activity of 1-(2,4-Dichlorobenzoyl)4-substituted Thiosemicarbazides, 1,2,4-Triazoles and Their Methyl Derivatives, J. Heterocyclic Chem., 21, 1225-1229 (1984).

[10] A. R. Jalilian, S. Sattari, M. Bineshmarvasti, A. Shafiee, M. Daneshtalab, Synthesis and in vitro antifungal and cytotoxicity evaluation of thiazolo- $4 H-1,2,4$-triazoles and 1,2,3-thiadiazolo-4H-1,2,4-triazoles-1,2,4-4Htriazoles-thiazoles-1,2,3-thiadiazoles, Arch. Der Pharmazie, 333, 347-354 (2000).

[11] N. Guelerman, S. Rollas, M. Uelgen, Synthesis and in vitro microsomal metabolism of 4-ethyl-5-(4-fluorophenyl)-2,4-dihydro-3H-1,2,4-triazole-3-thione and its potential metabolites, Boll. Chim. Farm., 137, 140-143 (1998).
[12] S. M. Rabea, N. A. El-Koussi, H. Y. Hassan, T. AbouiFadi, Synthesis of 5-phenyl-1-(3-pyridyl)-1H-1,2,4 triazole-3-carboxylic Acid Derivatives of potential Antiinflamatary Activity, Arch. der Pharmazie, 339, 32-40 (2006).

[13] M. Wujec, M. Pitucha, M. Dobosz, U. Kosikowska, A. Malm, Synthesis and potential antimycotic activity of 4 substituted-3-(thiophene-2-yl-methyl)-1,2,4triazoline-5-thiones, Acta Pharm., 54, 251-260 (2004).

[14] G. Sahin, E. Palaska, P. Kelicen, R. Demirdamar G. Altmok, Synthesis of some new 1-acylthiosemicarbazides, 1,3,4-oxadiazoles, 1,3,4-thiadiazoles and 1,2,4-triazole3-thiones and their anti-inflamatory activities, Arzneim. Forsch., 51, 478-484 (2001).

[15] A. R. Katritzky, S. Rachwal, B. Rachwal, The Chemistry of N-substituted Benzotriazoles. Part 4. A Novel and Versatile Method for the Mono-N-alkylation of Aromatic and Heteroaromatic Amines, J. Chem. Soc. Perkin Trans. I, 1, 805-809 (1987).

[16] F. Collino, S. Volpe, Mannich bases of benzimidazoles, benzotriazoles and their analogs having pharmacological activity, Boll. Chim. Farm., 121, 328-331 (1982).

[17] J. Cruz, E. Gracia-Ochoa, M. Castro, Experimental and Theoretical Study of the 3-Amino-1,2,4-triazole and 2Aminothiazole Corrosion Inhibitors in Carbon Steel, $J$. Electrochem. Soc., 150, B26-B35 (2003).

[18] M. A. Quraishi, D. Jamal, Fatty acid triazoles: Novel corrosion inhibitors for oil well steel $(\mathrm{N}-80)$ and mild steel, J. Am. Oil Chem. Soc., 77, 1107-1111 (2000).

[19] R. L. Sung, B. H. Zoleski, U. S. P. 4 (278), 553 (1981); (Chem. Abstr. 1981, 95, 118196h).

[20] E. E. Dolgopolyi, E. A. Eminov, U.S.S.R.P. 761, 543 (1980); (Chem. Abstr. 1981, 94, 50010g).

[21] Nippon Oil Co. Ltd., Jpn. P. 81 (163), 195 (1981); (Chem. Abstr. 1982, 96, 194998a).

[22] J. Chim, U. S. P. 4 (264), 436 (1981); (Chem. Abstr. 1981, 95, 159907j).

[23] M. Lazarevic, V. Dimova, D. Molnar Gabor, V. Kakurinov, K. Colanceska, Synthesis of some $\mathrm{N}^{1}$-aryl/heteroarylaminomethyl/ethyl-1,2,4-triazoles and their antibacterial and antifungal activities, Heterocyclic Communications, 7 (6), 577-582 (2001).

[24] K. Colanceska, V. Dimova, V. Kakurinov, D. MolnarGabor, A. Buzarovska, Synthesis and antibacterial and antifungal activity of 4-substituted-5-aryl-1,2,4triazole, Molecules, 6, 815-824 (2001).

[25] N. Perisic-Janjic, M. Acinski, N. Janjic, M. Lazarevic, V. Dimova, Study of the lipophilicity of some 1,2,4-triazole derivatives by RPHPLC and TLC, Journal of Planar Chromatography, 13, 281-284 (2000).

[26] B. Spasovska-Gerasimova, S. Ilievska, K. Čolančeska, M. Lazarevic, V. Dimova, Tretment of cotton textile material with $\quad \mathrm{N}^{1}-[1-(1,2,4-$ triazole-1-yl)methyl)-4-amino1,2,4-triazole for imparting antimicrobial properties, Vlákna a textil, 9 (2), 46-49 (2002).

[27] S. Rollas, N. Kalyoncuoglu, D. Sür-Altiner, Y. Yegenoglu, 5-(4-Aminophenyl)-4-substituted-2,4-dihydro-3H-1,2,4-triazole-3-thiones: Synthesis and antibacerial and antifungal activities, Pharmazie, 48, 308309 (1993). 
[28] ACD-Lab software for calculationg the referred physicochemical properties, Chemsketh S.O.,

http: //www.acdlabs.com (last accessed: 01.04.2008)

[29] http://www.syrres.com/esc/est_kowdemo.htm (last accessed: 01.04.2008)

[30] Atkins, P.W. Quanta; Oxford University Press; Oxford, 1991.

[31] Origin - program package, Version 5,0, Microcal Software Inc., USA, 1997.
[32] V. Dimova, K. Colanceska Ragenovic, V. Kakurinov, QSAR of some $\mathrm{N}^{1}$-aryl/heteroarylaminometyl/ethyl1,2,4-triazoles. Part II: Antimicrobial activity against $B a$ cillus subtilis, Int. J. Mol. Sci., 7, 119-129 (2006).

[33] V. Dimova, K. Čolančeska, V. Kakurinov, QSAR of some $\quad \mathrm{N}^{1}$-aryl/hetero-arylaminomethyl/ethyl-1,2,4-triazoles. Part III: Antimicrobial activity against Salmonella enteritidis, Bull. Chem. Technol. Macedonia, 25 (1), 1-7 (2006). 